\title{
Attributes of Innovation and Management Accounting Changes
}

\author{
Davood Askarany \\ University of Auckland \\ E-Mail: d.askarany@auckland.ac.nz
}

\begin{abstract}
This study provides evidence for the adoption and diffusion of activity-based costing (ABC) in the Sultanate of Oman (as a developing country) and examines the significance of the effect of characteristics of innovation on the adoption and diffusion of $\mathrm{ABC}$ (as both a practice and a process). It further explains some of the variations in the ABC's adoption rates in the literature.

The findings show that the adoption and diffusion of ABC in Oman is not very popular. The results provide no conclusive evidence to support the significance of innovation characteristics on the adoption and diffusion of $\mathrm{ABC}$ in developing countries, such as Oman. While the diffusion of innovation theory suggests that innovation characteristics could have a significant influence on the adoption and diffusion of innovations, current study suggests that the diffusion of certain innovations (such as ABC in our study) in a particular environment and situation (such as developing countries-case of Oman in our study) could follow other ideologies (e.g., fad fashion philosophy or institutional theory) rather than the diffusion of innovation theory.
\end{abstract}

Keywords: Activity-Based Costing, Innovation Characteristics, The Diffusion of Innovation and Economic Theory

\section{INTRODUCTION}

Research on usefulness, capability, and adoption and diffusion of ABC (as a potential solution to deal with the lack of efficiency and capability of traditional cost and management accounting practices) has been one the most attractive topics in the area of costing in the past three decades (Askarany, Brierley, \& Yazdifar, 2012; Askarany, Smith, \& Yazdifar, 2007; Askarany \& Yazdifar, 2012; Baird, 2007; Cannavacciuolo, Iandoli, Ponsiglione, \& Zollo, 2012). Highlighting the advantages and capabilities of $\mathrm{ABC}$, an accumulated body of literature suggests that $\mathrm{ABC}$ can 
contribute to the organisational performance in many ways, such as cost reduction, cost estimation, performance measurement, and the like (Homburg, 2005; Satoglu, Durmusoglu, \& Dogan, 2006; Thyssen, Israelsen, \& Jørgensen, 2006). However, despite its reported merits in the literature, the adoption of $A B C$ is not very popular in general (Al-Omiri \& Drury, 2007b; Askarany \& Smith, 2008; Askarany \& Yazdifar, 2007). Furthermore, evidence of how organisations in developing countries receive ABC is scant.

Addressing the diffusion of $\mathrm{ABC}$, many studies have investigated the effects of a vast majority of contextual factors on the diffusion of ABC (Al-Omiri \& Drury, 2007b; Askarany \& Smith, 2004; Baird, 2007). Many of these studies have produced mixed and inconsistent results (Al-Omiri \& Drury, 2007b; Baird, 2007; Libby \& Waterhouse, 1996).

According to the economic theory (Van Helden \& Tillema, 2005), organisations are more likely to adopt a new technique (innovation) if it adds value to the organisation or improves organisational performance (e.g., added value, profit, quality, etc.). In other words, the benefits of an innovation, its relative advantage over the current practice, its costs, its complexity, and other factors, can be considered as factors that determine the adoption of an innovation, and they should be evaluated by the economic theory. These determining factors are called 'characteristics of innovation' under the diffusion of innovation theory (Askarany, 2009; Rogers, 2003). Both the economic and diffusion of innovation theories suggest that these factors determine the economic preferences of an innovation and thus its adoption and diffusion. However, to our knowledge, no study has examined these theories in relation to $\mathrm{ABC}$ in developing countries. Hence, the current study was designed to provide evidence of the adoption of and diffusion of ABC in the Sultanate of Oman (as a developing country) and examine the significance of the effect of innovation characteristics on the adoption and diffusion of ABC in practice.

The remainder of the paper is structured as follows. Next section presents the literature review, followed by the research methodology, the findings, and finally discussion, implications, and conclusions. 


\section{LITERATURE REVIEW}

The prominent argument about ABC is that it can cope with some of the shortcomings of traditional accounting techniques, such as being too late, too aggregated, and too distorted (Gosselin, 1997; Innes \& Mitchell, 1991). However, despite its reported merits in the literature, the survey-based evidence suggests that the adoption of $\mathrm{ABC}$ is not a very popular option and in many cases (Al-Omiri \& Drury, 2007b; Askarany \& Smith, 2008; Askarany \& Yazdifar, 2007).

Askarany and Yazdifar (2012) reported a huge variation (from 4\% to 78\%) in the adoption of $\mathrm{ABC}$ in the literature. To investigate the implementation of ABC, many studies have tried to specify the contextual factors influencing the adoption and diffusion of ABC in practice (Askarany et al., 2007; Baird, 2007). However, most of the reported influencing factors do not appear to have a significant influence on the diffusion process of cost and management accounting innovations. For example, Booth and Giacobbe (1998) found no support for the effect of a various influencing factors classified as "demand and supply factors" on the diffusion of accounting innovations.

Some mixed results have also been reported in terms of the levels of association between some of the examined contextual factors (e.g., business size and business industry) and the adoption of ABC in the literature (Damanpour, 1988; Downs \& Mohr, 1976; Rogers, 1995; Wolfe, 1994). For example, while some studies suggest that larger firms are more likely to adopt ABC (Al-Omiri \& Drury, 2007b; Bjøornenak, 1997; Innes \& Mitchell, 1995; Krumwiede, 1998), other studies suggest no relationship between business size and the extent of ABC adoption (Cohen, Venieris, \& Kaimenaki, 2005; Gosselin, 1997; Libby \& Waterhouse, 1996). As another example, the literature indicates some controversy regarding the relationship between organisational industry (manufacturing versus non-manufacturing) and the extent of the adoption of ABC (John Innes, Mitchell, \& Sinclair, 2000; Pierce, 2004). For instance, while some studies report a higher $\mathrm{ABC}$ adoption rate in nonmanufacturing than in manufacturing organisations (John Innes et al., 2000), other studies suggest the opposite (Pierce, 2004). These mixed and inconsistent results on the ABC adoption encourage further studies to search for other theory(ies) and probably other contextual factor(s) in relation to the ABC adoption in practice.

Van Helden and Tillema (2005, p.338) used both 'economic' and 'institutional' reasoning to provide a comprehensive theoretical explanation for the adoption and diffusion of innovation. Their selection of 'economic reasoning' is due to the added value (e.g., effectiveness and efficiency, cost saving, etc.), which a new technique is supposed to offer. Their selection of 'institutional reasoning,' which is derived from 
neo-institutional and resource dependence theories, is due to the effect of institutional factors (e.g., rules and regulations, values and traditions, etc.) on the adoption and diffusion of innovation. Their overall conclusion is that two above-mentioned theoretical angles (economic and institutional theories) can provide similar as well as complementary explanations for the adoption and diffusion of innovation. However, the diffusion of innovation theory is one of the most cited theories to explain the diffusion innovation is (Rogers, 2003).

The diffusion of innovation theory supports both economic and institutional theories. According to the diffusion of innovation theory (D Askarany, 2009; Rogers, 2003), 'characteristics of innovation' in terms of its relative advantages (economic theory) and 'characteristics of adopters' in terms rules, regulation, and values, among others, related to the potential adopters of the innovation (institutional theory) influence the adoption and diffusion of an innovation.

To measure the attributes of innovations, Moore and Benbasat (1991) developed a set of general scale items. Testing almost all introduced instruments (in the field of characteristics of innovations), Moore and Benbasat (1991) prepared a refined instrument to measure different characteristics of innovations. After conducting several surveys and performing a number of statistical tests, they concluded that their instrument has high validity and reliability, and it could be used appropriately in most diffusion studies (please see Table 4 for the list).

Contributing to the literature and adopting Moore and Benbasat's (1991) developed instrument, this study examines the diffusion and adoption of $A B C$ in the Sultanate of Oman as a developing country through the lenses of the 'diffusion of innovation theory' in general as well as 'economic theory' in particular.

\section{RESEARCH METHOD}

The data used in this study was gathered using a survey questionnaire and a follow-up interview in Sultanate of Oman in 2011. A questionnaire was sent to 774 firms (through a random sample of $20 \%$ of the targeted populations) registered with Chamber of Commerce and Industry (OCCI) with a capital value of 250,000 Omani Riyals (one Riyal was just over \$US2.5 at the time of investigation in 2011).

To examine the extent of diffusion of $\mathrm{ABC}$ as a practice, respondents were asked to identify the adoption of $\mathrm{ABC}$ on a 5-point Likert-type scale (Abdel-Kader \& Luther, 2006; John Innes et al., 2000), where 1=“discussions have not taken place regarding the introduction of the technique”; $2=$ "a decision has been taken not to introduce the technique"; $3=$ "some consideration is being given to the introduction of the technique in the future"; $4=$ "the technique has been introduced on a trial basis"; 
and 5="the technique has been implemented and accepted".

To examine the level of the adoption of $\mathrm{ABC}$ as a process, the respondents were asked to identify the stage/level of adoption of ABC based on four main stages of ABC adoption addressed in the literature as follows: 1) activity analysis, 2) the identification of cost drivers, 3) allocation of costs to cost pools and finally, and 4) allocation of cost pools to products/services (Horngren, Datar, \& Rajan, 2012).

To examine the level of association between innovation characteristics and the adoption of $\mathrm{ABC}$ in practice, the respondents were asked to identify the importance of the influence of innovation characteristics (18 items listed before) on their decisions to adopt $\mathrm{ABC}$ based on following scale: very important $=1$; important $=2$; neutral $=3$; not very important $=4$; irrelevant $=5$.

\section{FINDINGS}

Overall, 116 completed questionnaires were received (plus 261 not completed or not delivered), providing a satisfactory response rate of 22.6\% (Al-Omiri \& Drury, 2007a, 2007b; Brown, Booth, \& Giacobbe, 2004). According to Krumwiede (1998), the normal response rate for these kinds of surveys is approximately $20 \%$, though many published surveys report lower response rates, such as $12.5 \%$.

Non-response bias was examined by comparing the information provided by early (first two weeks) and late (three weeks and more) respondents in the survey. The results showed no perceived difference between these responses, suggesting that nonresponse bias would not influence the outcomes. In other words, the responses of early and late respondents were independent and late respondents were an appropriate proxy for non-respondents. Please see Table 1 for more details.

Table 2 shows the extent of the diffusion of $\mathrm{ABC}$ as a practice. According to Table 2, 12.9\% of organizations have adopted and accepted ABC as a practice. Additional $8.6 \%$ of organisations have implemented $\mathrm{ABC}$ on a trial basis (but not accepted it yet). In other words, $21.5 \%(12.9 \%+8.6 \%)$ of organisations have experienced $\mathrm{ABC}$ (either on a trial basis or as an accepted technique). However, these findings show that most organisations are not using $\mathrm{ABC}$ in practice, as the percentage of non-adopters is greater compared to the percentage of those who have adopted and accepted the ABC. 
Table 1 Chi-Square Test of Independence: Regarding The Adoption of The ABC

(Containing P Value at 95\% Confidence Level)

\begin{tabular}{|c|c|c|c|c|c|c|}
\hline & \multicolumn{5}{|c|}{ Activity based costing ('stages' of adoption) } & \multirow[b]{2}{*}{ Total } \\
\hline & $\begin{array}{l}\text { Discussions } \\
\text { have not taken } \\
\text { place } \\
\text { regarding the } \\
\text { introduction }\end{array}$ & $\begin{array}{l}\text { A decision has } \\
\text { been taken not } \\
\text { to introduce } \\
\text { this practice } \\
\end{array}$ & $\begin{array}{l}\text { Some consideration } \\
\text { is being given to } \\
\text { the introduction of } \\
\text { this }\end{array}$ & $\begin{array}{l}\text { This practice } \\
\text { has been } \\
\text { introduced on a } \\
\text { trial basis }\end{array}$ & $\begin{array}{c}\text { This practice has } \\
\text { been } \\
\text { implemented and } \\
\text { accepted }\end{array}$ & \\
\hline $\begin{array}{l}\text { Early } \\
\text { Responses }\end{array}$ & 27 & 3 & 9 & 4 & 7 & 50 \\
\hline Late Responses & 24 & 14 & 14 & 6 & 8 & 66 \\
\hline Total & 51 & 17 & 23 & 10 & 15 & 116 \\
\hline
\end{tabular}

Chi-Square Tests

\begin{tabular}{lccc} 
& Value & df & Sig \\
\hline Pearson Chi-Square & $6.770^{\mathrm{a}}$ & 4 & 0.149 \\
\hline Likelihood Ratio & 7.251 & 4 & 0.123 \\
\hline $\begin{array}{l}\text { Linear-by-Linear } \\
\text { Association }\end{array}$ & 0.417 & 1 & 0.518 \\
\hline N of Valid Cases & 116 & & \\
\hline
\end{tabular}

Table 2 The Adoption of ABC as A Practice

\begin{tabular}{cccccc}
\hline $\begin{array}{c}\text { No } \\
\text { discussion }\end{array}$ & $\begin{array}{c}\text { Decided not } \\
\text { to introduce }\end{array}$ & $\begin{array}{c}\text { Some consideration is } \\
\text { given }\end{array}$ & $\begin{array}{c}\text { Introduced on } \\
\text { trial basis }\end{array}$ & $\begin{array}{c}\text { Implemented } \\
\text { and accepted }\end{array}$ & Total \\
\hline 51 & 17 & 23 & 10 & 15 & 116 \\
\hline $44 \%$ & $14.7 \%$ & $19.8 \%$ & $8.6 \%$ & $12.9 \%$ & $100 \%$ \\
\hline
\end{tabular}

Table 3 shows the level of the adoption of ABC as a process in the following order 1) activity analysis, 2) the identification of cost drivers, 3) allocation of costs to cost pools, and 4) allocation of cost pools to products/services (Horngren et al., 2012).

According to Table 3, 17.2\% of organisations (both on a trial basis and those that have implemented and accepted the technique) have proceeded with the full adoption of the technique (implementing all four stages) while $21.5 \%(12.9 \%+8.6 \%)$ adopted $\mathrm{ABC}$ as a practice (in general). This explains inconsistent results (in terms of different adoption rates for $\mathrm{ABC}$ ) in the literature, and it can be considered as an important contribution to the literature. In other words, this study suggests that some of the high adoption rates reported in the literature (e.g., Chenhall \& Langfield-Smith, 1998) may just refer to the adopters of earlier stages of $A B C$ but not to the adopters of all four stages of the technique, as shown in this study. 
Table3 The Adoption of ABC as A Process

\begin{tabular}{|c|c|c|}
\hline Stages of adoption of $\mathrm{ABC}$ & Numbers & Percept \\
\hline (1) Activity analysis (AA) & 29 & $25 \%$ \\
\hline (2) The identification of cost drivers (ACA1) & 22 & $19 \%$ \\
\hline (3) Allocation of costs to cost pools (ACA2) & 29 & $25 \%$ \\
\hline (4) Allocation of cost pools to products/services (ABC) & 20 & $17.2 \%$ \\
\hline Not relevant (not adopted) & 16 & $13.8 \%$ \\
\hline Total & 116 & $100 \%$ \\
\hline
\end{tabular}

Table 4 examines the level of associations between characteristics of innovation and the adoption of ABC both as a practice and as a process. According to Table 4, the findings show no significant association between characteristics of innovation and the adoption of ABC neither as a practice nor as a process in the Sultanate of Oman (as an example of developing countries).

The diffusion of innovation theory (Rogers, 2003) suggests that innovation characteristics can have a significant influence on the adoption and diffusion of innovations. However, as with some of the extant literature (Abrahamson, 1991; Eric Abrahamson, 1996; Lapsley \& Wright, 2004), current study revealed that the diffusion of particular innovations (such as ABC in our study) in certain environment and situations (such as those in developing countries like Oman in our study) might follow other ideologies, such as fad fashion philosophy (e.g., Abrahamson, 1991; Abrahamson, 1996; Lapsley \& Wright, 2004) or institutional theory (e.g., Van Helden \& Tillema, 2005). Further studies are recommended to investigate the influence of other contextual factors, such as organisational factors and factors external to the organisations, on the adoption and diffusion of ABC in developing countries. 
Table 4 Characteristics of Innovation

\begin{tabular}{|l|c|c|}
\hline & $\begin{array}{c}\text { ABC as } \\
\text { a practice }\end{array}$ & $\begin{array}{c}\text { ABC as a } \\
\text { process }\end{array}$ \\
\hline Its ability to get the job/service done quicker & 0.559 & 0.788 \\
\hline Its ability to improve the quality of the job/service & 0.542 & 0.370 \\
\hline Its ability to do the job/service easier & 0.355 & 0.684 \\
\hline Its ability to increase the overall effectiveness of the job/service & 0.669 & 0.103 \\
\hline Its ability to offer greater control over work processes (gob/service) & 0.291 & 0.212 \\
\hline Being compatible with all aspects of existing processes (job/service) & 0.675 & 0.628 \\
\hline Fitting well with the way I/organisation like to work & 0.261 & 0.123 \\
\hline Fitting into my/organisation work style & 0.054 & 0.423 \\
\hline Being easy to learn how to operate & 0.579 & 0.321 \\
\hline Offering clear and understandable interaction with the technique & 0.222 & 0.182 \\
\hline Being easy to use/implement & 0.698 & 0.481 \\
\hline Being easy to get the technique to do what I/organisation want it to do & 0.824 & 0.412 \\
\hline Having no difficulty telling others about the results of using the technique & 0.439 & 0.252 \\
\hline Being able to communicate to others the consequence of using the technique & 0.674 & 0.063 \\
\hline Being able to see the results of using the technique clearly & 0.620 & 0.527 \\
\hline Being able to explain why using the technique may or may not be beneficial & 0.958 & 0.843 \\
\hline Being able to try the technique before deciding to implement it (or not) & 0.633 & 0.466 \\
\hline Being allowed to use the technique on a trial basis long enough to see what it could do & 0.764 & 0.611 \\
\hline
\end{tabular}

\section{DISCUSSION, IMPLICATIONS, AND CONCLUSIONS}

This study is the first in the literature to examine the adoption and the diffusion of ABC through the lens of 'economic theory' as well as the 'diffusion of innovation theory.'

According to the findings, $12.9 \%$ of organizations have adopted and accepted ABC as a practice. Additional 8.6\% of organisations have implemented ABC on a trial basis (but not accepted it). In other words, $21.5 \%(12.9 \%+8.6 \%)$ of organisations have tried $\mathrm{ABC}$ (either on a trial basis or as an accepted technique).

Examining the adoption of $\mathrm{ABC}$ as a process, the findings show that $17.2 \%$ of organisations adopted the full or trial adoption of the technique (implementing all four stages) while $21.5 \%(12.9 \%+8.6 \%)$ of organisations adopted ABC as a practice. This can explain the inconsistent results (in terms of different adoption rates for ABC) in the literature and can offer an important contribution to the literature. In other words, this study suggests that some of the high adoption rates reported in the literature may just refer to the adopters of earlier stages of $A B C$ but not to the adopters of all four stages of the technique, as shown in this study.

The findings showed that the adoption and diffusion of $\mathrm{ABC}$ in Oman is not very popular, as most organisations are not using $\mathrm{ABC}$ in practice. Therefore, the results 
imply that further studies are needed to identify the reason/s for the slow adoption and diffusion of ABC in developing countries.

This study further contributes to the literature by examining the significance of the association between characteristics of innovation on the one hand and the adoption of $\mathrm{ABC}$ as a practice and process on the other hand. According to the findings, this study provides no conclusive evidence to support the significance of innovation characteristics on the adoption and diffusion of ABC in developing countries, such as Oman. While the diffusion of innovation theory suggests that innovation characteristics could have a significant influence on the adoption and diffusion of innovations, the current study suggests that the diffusion of certain innovations (such as $\mathrm{ABC}$ in our study) in particular environment and situations (such as developing countries like Oman in our study) could follow other ideologies (e.g., fad fashion philosophy or institutional theory) rather than the diffusion of innovation theory. Further studies should investigate the influence of other contextual factors, such as organisational factors and factors external to the organisations, on the adoption and diffusion of ABC in developing countries.

As with any survey, this study is subject to some limitations. Since the respondents were mostly management accountants, the reported adoption of ABC in organizations might have been biased. Another limitation relates to the selection of targeted population for this study. According to OCCI, the total number of registered organisations in the Sultanate of Oman was 167,960 at the beginning of 2011. However, after some investigation and negotiation with a number of academics, professionals, and practitioners in the Sultanate of Oman, it was suggested that most organisations with a capital value of less than 250,000 Riyals (such as small shops and family businesses) are less likely to have a proper accounting systems or necessary knowledge of ABC. Therefore, it was decided that the most appropriate approach would be to select our targeted sample from organisations with a capital value of 250,000 Omani Riyals or more (3427 organisations) as well as international organisations working in the country (439 organisations). Thus, generalizing the results of this study to other organizations should be done with caution.

\section{REFERENCES}

Abdel-Kader, M., \& Luther, R. (2006). Management accounting practices in the British food and drinks industry. British Food Journal, 108(5), 336-357. http://dx.doi.org/10.1108/00070700610661321 
Abrahamson, E. (1991). Managerial Fads and Fashions: The Diffusion and Rejection of Innovations. Academy of Management Review, 16(3), 586-612. http://dx.doi.org/10.5465/AMR.1991.4279484

Abrahamson, E. (1996). Management fashion. Academy of Management Review, 21(1), 254-285.

Al-Omiri, M., \& Drury, C. (2007a). Organizational and behavioural factors influencing the adoption and success of $\mathrm{ABC}$ in the UK. Cost Management, 21(6), 38-48. http://dx.doi.org/10.5465/AMR.1996.9602161572

Al-Omiri, M., \& Drury, C. (2007b). A survey of factors influencing the choice of product costing systems in UK organizations. Management Accounting Research, 18(4), 399-424. http://dx.doi.org/10.1016/j.mar.2007.02.002

Askarany, D. (2009). Innovation Generation and Innovation Adoption. In M. Khosrow-Pour (Ed.), Encyclopedia of Information Science and Technology (pp. 2048-2054). Hershey: IDEA Group Publishing,.

Askarany, D., Brierley, J. A., \& Yazdifar, H. (2012). The effect of innovation characteristics on activity-based costing adoption. International Journal of Managerial and Financial Accounting (IJMFA), 4(3), 291-313. http://dx.doi.org/10.1504/IJMFA.2012.047854

Askarany, D., \& Smith, M. (2004). Contextual factors and administrative changes. Issues in Informing Science and Information Technology Journal, 1, 179-188.

Askarany, D., \& Smith, M. (2008). Diffusion of innovation and business size: a longitudinal study of PACIA. Managerial Auditing Journal, 23(9), 900-916. http://dx.doi.org/10.1108/02686900810908445

Askarany, D., Smith, M., \& Yazdifar, H. (2007). Technological Innovations, Activity Based Costing and Satisfaction. JABM: Journal of Accounting, Business \& Management, 14, 53-63. http://dx.doi.org/10.1108/02686900810908445

Askarany, D., \& Yazdifar, H. (2007). Why ABC is not widely implemented? International Journal of Business Research (IJBR), 7(1), 93-98.

Askarany, D., \& Yazdifar, H. (2012). An Investigation into the Mixed Reported Adoption Rates for ABC: Evidence from Australia, New Zealand and the UK. International Journal of Production Economics, 135(1), 430-439. http://dx.doi.org/10.1016/j.ijpe.2011.08.017

Baird, K. (2007). Adoption of activity management practices in public sector organizations. Accounting and Finance, 47(4), 551. http://dx.doi.org/10.1111/j.1467-629X.2007.00225.x 
Bjøornenak, T. (1997). Diffusion and accounting: the case of ABC in Norway. Management Accounting Research, 8(1), 3-17. http://dx.doi.org/10.1006/mare.1996.0031

Booth, P., \& Giacobbe, F. (1998, September). The impact of demand and supply factors in the diffusion of accounting innovations: the adoption of Activity-Based Costing in Australian Manufacturing Firms. Paper presented at the Management Accounting Conference, Sydney.

Brown, D. A., Booth, P., \& Giacobbe, F. (2004). Technological and organizational influences on the adoption of activity-based costing in Australia. Accounting and Finance, 44(3), 329-356. http://dx.doi.org/10.1111/j.1467-629x.2004.00118.x

Cannavacciuolo, L., Iandoli, L., Ponsiglione, C., \& Zollo, G. (2012). An analytical framework based on AHP and activity-based costing to assess the value of competencies in production processes. International Journal of Production Research, 50(17), 4877-4888. http://dx.doi.org/10.1080/00207543.2012.657974

Chenhall, R. H., \& Langfield-Smith, K. (1998). Adoption and benefits of management accounting practices: an Australian study. Management Accounting Research, 9(1), 1-19. http://dx.doi.org/10.1006/mare.1997.0060

Cohen, S., Venieris, G., \& Kaimenaki, E. (2005). ABC: adopters, supporters, deniers and unawares. Managerial Auditing Journal, 20(8/9), 981. http://dx.doi.org/10.1108/02686900510625325

Damanpour, F. (1988). Innovation type, radicalness, and the adoption process. Communication Research, 15 , 545-567. http://dx.doi.org/10.1177/009365088015005003

Downs, G. W., \& Mohr, L. B. (1976). Conceptual issues in the study of innovations. Administrative Science $\quad$ Quarterly, 700-714. http://dx.doi.org/10.2307/2391725

Gosselin, M. (1997). The Effect of Strategy and Organizational Structure on the adoption and implementation of Activity Based Costing. Accounting Organizations and Society, 22(2), 105-122. http://dx.doi.org/10.1016/S03613682(96)00031-1

Homburg, C. (2005). Using relative profits as an alternative to activity-based costing. International Journal of Production Economics, 95(3), 387-397. http://dx.doi.org/10.1016/j.ijpe.2004.02.002

Horngren, T., Datar, S. M., \& Rajan, M. V. (2012). Cost Accounting A Managerial Emphasis (14 ed.). Essex, England: Pearson.

Innes, J., \& Mitchell, F. (1991). A survey of activity-based costing in the U.K.'s largest companies. Management Accounting Research, 6(2), 137-153. 
Innes, J., \& Mitchell, F. (1995). A survey of activity-based costing in the U.K.'s largest companies. Management Accounting Research, June, 137-153. http://dx.doi.org/10.1006/mare.1995.1008

Innes, J., Mitchell, F., \& Sinclair, D. (2000). Activity-based costing in the U.K.'s largest companies: a comparison of 1994 and 1999 survey results. Management Accounting Research, 11(3), 349-362. http://dx.doi.org/10.1006/mare.2000.0135

Krumwiede, K. R. (1998). The Implementation Stages of Activity-Based Costing and the Impact of Contextual and Organizational Factors. Journal of Management Accounting Research, 10, 239-277.

Lapsley, I., \& Wright, E. (2004). The diffusion of management accounting innovations in the public sector: a research agenda. Management Accounting Research, 15(3), 355-374. http://dx.doi.org/10.1016/j.mar.2003.12.007

Libby, T., \& Waterhouse, J. H. (1996). Predicting change in management accounting systems. Journal of Management Accounting Research, 8, 137-150.

Moore, G. C., \& Benbasat, I. (1991). Development of an Instrument to Measure the Perceptions of Adopting an Information Technology Innovation. Information Systems Research, 2(3), 192-222. http://dx.doi.org/10.1287/isre.2.3.192

Pierce, B. (2004). Activity based costing. Accountancy Ireland, 36(5), 28.

Rogers, E. M. (1995). Diffusion of Innovation (4th ed.). New York: Free Press.

Rogers, E. M. (2003). Diffusion of innovations. New York: Free Press.

Satoglu, S. I., Durmusoglu, M. B., \& Dogan, I. (2006). Evaluation of the conversion from central storage to decentralized storages in cellular manufacturing environments using activity-based costing. International Journal of Production Economics, 103(2), 616-632. http://dx.doi.org/10.1016/j.ijpe.2005.12.003

Thyssen, J., Israelsen, P., \& Jørgensen, B. (2006). Activity-based costing as a method for assessing the economics of modularization--A case study and beyond. International Journal of Production Economics, 103(1), 252-270. http://dx.doi.org/10.1016/j.ijpe.2005.07.004

Van Helden, G. J., \& Tillema, S. (2005). IN SEARCH OF A BENCHMARKING THEORY FOR THE PUBLIC SECTOR. Financial Accountability \& Management, 21(3), 0267-4424. http://dx.doi.org/10.1111/j.02674424.2005.00224.x

Wolfe, R. A. (1994). Organizational innovation: review, critique and suggested research directions. Journal of Management Studies, 31(3), 405-431. http://dx.doi.org/10.1111/j.1467-6486.1994.tb00624.x 